García-Martínez et al. Promoting Professional Development for Teachers Through a Scale of Competence Assessment.

\title{
Promoting Professional Development for Teachers Through a Scale of Competence Assessment
}

\author{
Inmaculada García-Martínez * \\ University of Granada \\ Miguel Pérez-Ferra \\ University of Jaén \\ José Luis Ubago Jiménez \\ University of Granada \\ Rocío Quijano-López \\ University of Jaén \\ *Corresponding Author: igmartinez@ugr.es \\ Received: 04.07.2019 \\ Revision: 06.08.2019 \\ Accepted: 12.09 .2019
}

How to cite this paper: García-Martínez, I., Pérez-Ferra, M., Jiménez, J. L. U., \& Quijano-López, R. (2019). Promoting professional development for teachers through a scale of competence assessment. Research in Social Sciences and Technology, 4(2),147-162.

\begin{abstract}
Competencies are a key factor in the professional development of teachers. Additionally, Information and Communication Technologies (ICTs) in education are becoming increasingly important due to their potential in the field of education. The combination of both makes it easier to perform a comprehensive assessment of the level of competences of students in the Teacher Degree. The design of tasks and activities in order to promote their assessment enable classroom intervention. Indeed, this paper presents how ICTs have been used in university teaching. In order to respond to the evolution of training needs, we present a valid and reliable evaluation tool for professional competencies and learning results for prospective teachers (Pre-School and Primary Education). We applied for students from the Teacher Degree in their practicum period. Indeed, different learning and assessment tasks have been designed, some related to "correct" or "incorrect" teaching practices. This implies that the students have not only to do their tasks but to identify and to differentiate what is correct in their professional development. Finally, the instrument enables the assessment of the level of professional competencies acquired by prospective teachers during their training period.
\end{abstract}

Keywords: Teacher Training, Professional competencies, Online assessment program, Preservice Teacher Education, Teacher Degree 
García-Martínez et al. Promoting Professional Development for Teachers Through a Scale of Competence Assessment.

\section{Introduction}

Higher education is undergoing a pedagogical renewal (Fullan \& Langworthy, 2014) that has transformed the teaching and learning processes, incorporating Information and Communication Technologies (ICTS) in order to fit the demands placed on society (Escudero, Martínez-Domínguez, \& Nieto, 2018).

In this regard, the formative programs of teaching degrees have undergone great modifications (Pérez-Ferra \& Quijano-López, 2018), including a set of competencies (Quijano-López, PérezFerra, García-Martínez, \& Ocaña-Moral, 2016) that teachers must acquire in order to ensure high-quality teaching resulting in effective student learning processes (Louis, 2007).

This transformation is not only reflected in the use of new teaching methods and skills but is also evident in the type of assessment carried out (De Marco et al., 2015). There is a growing trend in the use of ICTs as a way of measuring teachers' professional competencies during their training period (Cano-García, 2015).

This is exemplified by the studies regarding the design of an instrument to measure the teaching performance by students in the Education Degree. More specifically on the use of ICT, the research developed by Prendes, Castañeda, and Gutierrez (2010) analyzes the competencies required for future teachers to integrate ICT in the classroom, using an adaptation of the questionnaire by Cabero and Llorente (2006). Other studies such as that by Etxabe-Urbieta, Aranguren-Garayalde, and Losada-Iglesias (2011) have opted for the rubrics to evaluate the teaching and learning process of future teachers.

Likewise, ICTs have provided new learning environments in which instructional processes can be developed, oriented towards collaboration and sharing (Rincón-Gallardo \& Fullan, 2016). As a result, barriers of space and time are broken down and teachers' opportunities to learn professionally both from their own practices and from their colleagues are increased. If the intention is to create competent teachers, it is essential to look for ways in which they can professionalize their figure (García-Martínez \& Martín-Romera, 2019). In this regard, the evaluation of professional teaching skills, either in virtual environments or through the use of technological platforms and resources, is a priority (Ruiz-Morales, García-García, BiencintoLópez, \& Carpintero, 2017).

Different studies have analyzed the benefits of virtual learning environments and technology for teachers and students (Magen-Nagar \& Shonfeld, 2018; Tarman \& Yuksel, 2014). In this regard, Marín-Díaz and Cabero (2019) consider that the exponential growth of virtual training environments has influenced teachers' ways of interacting (Lim \& Newby, 2019). In fact, one observes an emerging research trend that points to personal learning environments and the use of technological tools and platforms such as Moodle (Brahimi \& Sarirete, 2015; Tarman \& 
García-Martínez et al. Promoting Professional Development for Teachers Through a Scale of Competence Assessment.

Baytak, 2012) as the path to achieving an education for the knowledge society (McNaughton et al., 2018; Şahin \& Uluyol, 2016).

However, to ensure that teachers and students are prepared to face the challenges that Web 2.0 and even Web 3.0 offer, it is necessary that they have proficiency in technological skills (EI Mhouti et al., 2017).

This research justifies the importance of future teachers acquiring the professional skills required for their future professional development while highlighting the usefulness of an effective assessment system to judge them. Following this approach, a Competence Assessment Scale designed and validated within an innovation project is presented.

\section{Method}

The present paper is inscribed within an interpretative paradigm (Habermas, 1982). In particular, an exploratory and interpretative study is undertaken (Hernández-Sampieri, Fernández-Collado, \& Baptista, 2014), using the case study as a strategy. Likewise, quantitative and qualitative methods are applied to respond to the proposed objectives (Tójar, 2006).

\section{Research objectives}

a) Know the level of knowledge in professional competencies that pre-service teachers acquire in their teacher training period.

b) Analyze the impact of ICT on teacher professional development during their training period.

c) Design an online evaluation program for assessing professional competencies in a teacher by creating an innovative resource that allows evaluation of online training.

\section{Participants}

The study was carried out with 407 students from the third and fourth year of the Primary Education Degree and Pre-School Education Degree at the University of Jaén. The ages of the participants ranged from 21-29 years old.

\section{Procedure}

In this paper, we identified two clearly delimited phases. In the first, an instrument was created to evaluate four basic workable competences: Organize and promote learning situations, team work, use of new technologies, and organizing self-continuous training. To guarantee its validity and reliability, 15 primary and pre-school teachers were involved, along with extensive experience in schools and a strong training in competencies. 
García-Martínez et al. Promoting Professional Development for Teachers Through a Scale of Competence Assessment.

After the design of the instrument, there was a program design phase for the evaluation of teachers' professional competencies, which was applied on a pilot level.

More than just the conceptual aspect, the tasks proposed for assessing teachers' professional competencies were based on managing and applying what had been learned. Likewise, these tasks focus on identifying desirable teaching practices in their professional development.

\section{Results}

For the assessment of each competence, we designed a specific activity in which students were asked to put into practice the knowledge acquired. The research is contextualized in a course of Nature Sciences in the Degrees of Primary Education and Pre-School Education. The results are presented according to the objectives of the research. First of all, it exposes the level of knowledge of several professional competences acquired in this period from an online scale of evaluation of competences designed for this study. Finally, the Technological Competence is examined, analyzing the impact of ICTS on teacher professional development during their training period.

Thus, in order to verify the level of training in the teacher's professional competence "Organize and promote situations," an activity was designed where students had to work with concrete content during each educational stage where they will work as teachers. In particular, the contents were the growth and development of plants and, moreover, orientation through cardinal knowledge.

In the first case, growth and development of plants, students must demonstrate their scientific knowledge through observation, experimentation, obtaining results, studying those results, and expressing conclusions. This activity was evaluated through a report detailing the whole process followed to carry out the proposed activity, through a blog. Thus, it not only acquired the contents of the activity itself but also showed knowledge about both digital competence and scientific competence. In the report, the assessment was made of the content knowledge, as well as its didactic transfer, identifying the curricular elements to be used, designed, and proposed for future teaching students. With respect to the results obtained, it was found that students had difficulties organizing the contents according to the scientific method. Specifically, most of the difficulties found were in the phase of studying these results and expressing conclusions. In this regard, it could be stated that the future teachers were capable of observing, experimenting, and obtaining results following the imposed guidelines but were unable to structure knowledge, synthesize it, and carry out higher-order functions; in short, they produced a report in which they demonstrated whether they were capable of linking facts with inferences regarding other authors and with other data.

For the competence "teamwork," an activity of good teaching practices was proposed in which they were asked to design a didactic unit in small groups. We opted for the grouping of small 
García-Martínez et al. Promoting Professional Development for Teachers Through a Scale of Competence Assessment.

cooperative groups to work on interpersonal and social skills, empathy, dialogue, and consensus in order to reach a common objective. In this case, the content selected was the human body and its reproduction, suitable content in both educational stages. The assessment of this competence found a positive willingness by most students to work in teams. Above all, there was a clear trend to work in groups rather than individually. However, $30 \%$ of the students disagreed on the final work presented, which indicates difficulties in the processes of negotiation, dialogue, and consensus.

Due to the fact that the aim was to evaluate the students' capacity to apply knowledge, the activity of the competence "Use new technologies" was formulated in a negative sense. Thus, a teaching-related malpractice about the use of the digital whiteboard was used as a model for the activity. As part of the activity, students were asked to carry out in situ an analysis of the use of the digital whiteboard in schools during the pre-school and primary education stages. Simultaneously, they were also asked to carry out an analysis of the technological materials produced by the publishers so that they could reflect on their suitability in the curriculum as well as the use that teachers make of them in the classroom. The results obtained for this competence were ambiguous. There was a strong coincidence when it was stated that there was widespread improper use of the digital whiteboard, given that it did not "take advantage" of the real possibilities it offered such as wikis, webquest, and MOOCs, among others. In the case of the analysis of the technological materials designed by the editorial companies, approximately half of the future teachers $(47.65 \%)$ considered that they were adequate and conformed to the guidelines of the curriculum, while the rest thought otherwise. There was unanimity in declaring the scarce use that teachers made of these resources, the textbook being the material of preference for the majority of primary and pre-school teachers.

Observing the trends on the effective use of ICT in the classroom, in order to analyze the competence "Organize one's own continuous training," students were asked to create a personalized learning environment (PLE), coinciding with studies such as Şahin \& Uluyol (2016) in the Turkish context.

Among the guidelines for doing so, they were asked to perform the following tasks:

- Create a Twitter account and follow interesting people.

- Share ideas and findings on Twitter.

- Subscribe via RSS to blogs or other information sources (scientific journals).

- Start writing ideas and projects on a blog in WordPress, Blogger, or Posterous.

- Tag and share favorites on del.icio.us or diigo.

- Participate in some interesting social networks: Reducan, Elgg, Ning, Grou.ps.

- Add lifestreaming and share it. Subscribe to other interesting people on Facebook.

Given the familiarity that future teachers have with technology, most showed a high level of knowledge in this competence, although they acknowledged having had difficulties in 
García-Martínez et al. Promoting Professional Development for Teachers Through a Scale of Competence Assessment.

expressing their own ideas, an aspect related to the competence "Organize and promote situations."

Table 1 presents the relationship of each competence observed, with the tasks to be carried out to evaluate the level of achievement of these tasks.

\section{Table 1.}

List of competences to be analyzed by tasks.

\begin{tabular}{|c|c|}
\hline COMPETENCE & TASK \\
\hline \multicolumn{2}{|l|}{ ORGANIZE AND PROMOTE SITUATIONS } \\
\hline An activity must be carried out correctly. & $\begin{array}{l}\text { The development and growth of a plant is } \\
\text { proposed. } \\
\text { Making a compass. }\end{array}$ \\
\hline \multicolumn{2}{|l|}{ TEAMWORK } \\
\hline $\begin{array}{l}\text { Organize an activity in group with all its phases: schedule, } \\
\text { tasks distribution, process assessment. }\end{array}$ & $\begin{array}{l}\text { Design of a didactic unit about human } \\
\text { reproduction. }\end{array}$ \\
\hline \multicolumn{2}{|l|}{ USE OF NEW TECHNOLOGIES } \\
\hline $\begin{array}{l}\text { There is a bad practice about the digital whiteboard and they } \\
\text { must analyze and correct it. }\end{array}$ & $\begin{array}{l}\text { Analysis of the use of digital whiteboards in } \\
\text { schools in pre-school and primary education. } \\
\text { Analysis of CDs attached to educational materials. }\end{array}$ \\
\hline \multicolumn{2}{|l|}{ ORGANIZE ONE'S OWN CONTINUOUS TRAINING } \\
\hline Organize their own online training. & Organize a PLE. \\
\hline
\end{tabular}

\section{Discussion}

The development of professional teaching competencies is a key aspect of school improvement. This study addresses this by identifying four basic competencies for any teacher. Studies such as the one carried out by Gallego-Quicenos et al. (2017) have analyzed the perceptions of teachers in science education and their transfer to teaching, finding that students usually do not have a positive perception of science due to the approach adopted to teach it. In their study, they highlight the need for more creative experiences involving the social component, which would increase student motivation.

This social nature of knowledge and the capacity to learn and work with others is one of the conditions enclosed in the competence of "Teamwork." According to the results obtained, the participants of the study have a favorable attitude toward working with others, although they have difficulties when it comes to initiating negotiation and consensus processes (Forte \& Flores, 2013). In this regard, research such as that developed by Benoliel and Schechter (2018) or that of Duffy and Gallagher (2017) bet on the establishment of enabling conditions for collaboration as a way to combat professional isolation of teachers and get a group of teachers to work cooperatively. Often, these processes are initiated when there is a collective concern, as in the first case. Other times it happens when the need arises to work together to achieve a desirable goal for all (Radiæ-Šestiæ, Radovanoviæ, Milanoviæ-Dobrota, Slavkovic, \& LangoviæMiliæviæ, 2013). 
García-Martínez et al. Promoting Professional Development for Teachers Through a Scale of Competence Assessment.

Furthermore, ICT provides multiple opportunities and challenges for teachers. Not only is it necessary for them to show competence in the use of ICT tools, but they are also required to make didactic use of them. There has been a large amount of international investigation on this subject, highlighting the insufficient pedagogical training that future teachers often have to face these challenges (Jiang, Tang, Peng, \& Liu, 2018; Khan, 2017).

As for the capacity of future teachers to "Organize their own continuous training," studies such as that of Tour (2016) have focused on the capacity of teachers to establish networks and initiate self-starting professional learning processes, highlighting the positive impact of technologies. In this area, ongoing training through virtual learning environments is positioned as a powerful way to professionalize teachers and develop effective teaching practices (McNaughton et al., 2018).

\section{Conclusions}

This study presents the findings from research carried out at the University of Jaén with students from the Primary Education Teacher Degree and the Pre-School Education Teacher Degree. The first research objective was that of understanding the level of knowledge in professional competencies that pre-service teachers acquire in their teacher training period. To this end, the aim was to analyze four important basic skills that teachers must possess for their subsequent professional development: "Organize and promote situations," "Teamwork," "Use new technologies," and "Organize their own continuous training."

In the analysis, with regard to the competence "Organize and promote situations," it was found that students show difficulties when developing didactic transposition, abstracting what is relevant and expressing conclusions on specific contents. In the "Teamwork" competence, their high willingness to work in a team stands out at the same time that they show an insufficient ability to achieve consensus, an aspect that they must continue to improve in their subsequent professional practice. Regarding the third competence, "Using new technologies," students show knowledge in the use of new technologies, although they have insufficient knowledge to use them for pedagogical purposes, coinciding with numerous researches in the field. Despite this knowledge of how to use technologies, it has been detected that a very high percentage do not use specific software. For example, they do not know how to use all the potential of Word, such as change of format, inclusion of pagination, table format, inclusion and creation of images, etc. With regard to the competence "Organize your own continuous training," it has been shown that future teachers are inclined to use ICT in their training but have difficulties in carrying out tasks in which they have to express their own ideas and make value judgements.

The second research objective was to analyze the impact of ICT on teacher professional development during their training period. Students are familiar with the use of ICTs, as they have been trained in the Technological Era; however, they do not show enough pedagogical 
knowledge about the use of ICTs to integrate them into the design of teaching and learning processes. In this respect, there is a demand for specific programs on ICT literacy to reduce this situation. This is probably because they have learned to think about an activity and apply it but have not thought about how to evaluate it in terms of competence assessment or meaningful learning. This is a deficiency to be taken into account.

Finally, we present an example of a scale of evaluation of professional teaching competences, validated by 15 practicing teachers, responding to the third objective of this work, designing an online evaluation program for assessing professional competencies in a teacher, by creating an innovative resource that allows evaluation of online training (see Appendix). 
García-Martínez et al. Promoting Professional Development for Teachers Through a Scale of Competence Assessment.

\section{References}

Benoliel, P., \& Schechter, C. (2018). Teamwork doubting and doubting teamwork. Improving Schools, 21(3), 225-239.

Brahimi, T., \& Sarirete, A. (2015). Learning outside the classroom through MOOCs. Computers in Human Behavior, 51, 604-609.

Cabero, J., \& Llorente, M. (Eds.). (2006). La rosa de los vientos: Dominios tecnológicos de las TIC por los estudiantes. Sevilla: Grupo de Investigación Didáctica.

DeMarco, L., Panzarella, K., Ferro, H., Pownall, L., Case, A., Nowakowski, P., \& Cieri, N. (2015). Outcomes of an interprofessional simulation curriculum. Journal of Applied Research in Higher Education, 7(2), 453-468.

Duffy, G., \& Gallagher, T. (2017). Shared education in contested spaces: How collaborative networks improve communities and schools. Journal of Educational Change, 18(1), 107134.

El Mhouti, A., Nasseh, A., Erradi, M., \& Vasquèz, J. M. (2017). Enhancing collaborative learning in Web 2.0-based e-learning systems: A design framework for building collaborative elearning contents. Education and Information Technologies, 22(5), 2351-2364.

Escudero, J. M., Martínez-Domínguez, B., \& Nieto, J. M. (2018). Las TIC en la formación continua del profesorado en el contexto español: ICT in continuing teacher training in the Spanish context. Ministerio de Educación.

Forte, A. M., \& Flores, M. A. (2013). Potenciar o desenvolvimento profissional e a colaboração docente na escola. Cadernos de Pesquisa, 42(147), 900-919.

Fullan, M., \& Langworthy, M. (2014). A rich seam: How new pedagogies find deep learning. London: Pearson.

Gallego-Quiceno, D. E., Bustamante-Penagos, L., Gallego-Ramírez, L., Salcedo-Diaz, L., Gava, M., \& Alfaro-Melendez, E. (2017). Estudio cuantitativo sobre las concepciones de ciencia, metodología y enseñanza para profesores en formación. Revista Lasallista de Investigación, 14(1), 144-161.

García-Martínez, I., \& Martín-Romera, A. (2019). Potenciando la coordinación pedagógica a través del liderazgo de los mandos medios en educación secundaria. Revisión sistemática. Bordón, 71(2), 55-70.

Habermas, J. (1982). Conocimiento e interés. Madrid: Taurus.

Hernández-Sampieri, R. Fernández-Collado, C., \& Baptista, P. (2014). Metodología de la Investigación (6a ed.). México: Mc Graw-Hill. 
García-Martínez et al. Promoting Professional Development for Teachers Through a Scale of Competence Assessment.

Jiang, H., Tang, M., Peng, X., \& Liu, X. (2018). Learning design and technology through social networks for high school students in China. International Journal of Technology and Design Education, 28(1), 189-206.

Khan, A. (2017). Blog-based professional development of English teachers in Mumbai: The potential of innovative practice under scrutiny. Australasian Journal of Educational Technology, 33(4), 88-106.

Lim, J., \& Newby, T. J. (2019). Preservice teachers' Web 2.0 experiences and perceptions on Web 2.0 as a personal learning environment. Journal of Computing in Higher Education, $1-27$.

Louis, K. (2007). Changing the culture of schools: Professional community, organizational learning, and trust. Journal of School Leadership, 16(4), 477-489.

Marín-Díaz, V., \& Cabero, J. (2019). Social networks in education: from innovation to educational research. RIED. Revista Iberoamericana de Educación a Distancia, 22(2), 2533.

McNaughton, S., Rosedale, N., Jesson, R. N., Hoda, R., \& Teng, L. S. (2018). How digital environments in schools might be used to boost social skills: Developing a conditional augmentation hypothesis. Computers \& Education, 126, 311-323.

Pérez-Ferra, M., \& Quijano-López, R. (2018). Análisis del discurso de los estudiantes de Magisterio sobre la contribución del practicum al desarrollo de su identidad profesional docente. Educatio Siglo XXI, 36(2), 331-352.

Prendes, M. P., Castañeda, L., \& Gutiérrez, I. (2010). Competencias para el uso de TIC de los futuros maestros. Comunicar, 18(35), 175-182.

Quijano-López, R., Pérez-Ferra, M., García-Martínez, I., \& Ocaña-Moral, M. T. (2016). Idoneidad del desarrollo de criterios competenciales científicos en estudiantes del grado de Educación Primaria. En D. Caldevilla (dir.), Retos docentes universitarios como desafío curricular (pp. 1-11). Madrid, España: McGraw-Hill Education.

Radiæ-Šestic, M., Radovanovic, V., Milanovic-Dobrota, B., Slavkovic, S., \& Langoviæ-Milicvic, A. (2013). General and special education teachers' relations within teamwork in inclusive education: socio-demographic characteristics. South African Journal of Education, 33(3), $1-15$.

Ruiz-Morales, Y., García-García, M., Biencinto-López, C., \& Carpintero, E. (2017). Evaluación de competencias genéricas en el ámbito universitario a través de entornos virtuales: Una revisión narrativa. RELIEVE. Revista Electrónica de Investigación y Evaluación Educativa, 23(1), 1-15.

Şahin, S., \& Uluyol, Ç. (2016). Preservice teachers' perception and use of personal learning environments (PLEs). The International Review of Research in Open and Distributed Learning, 17(2), 141-161. 
Tarman, B \& Yuksel, Z. (2014). Roles and Use of Virtual Labs and WEB Sites in Social Studies Education. Baytak, A. (Ed.) Using Web Technologies in Education, Ankara: PegemA Press.

Tarman, B., \& Baytak, A. (2012). Children's online language learning: A constructionist perspective. Energy Education Science and Technology Part B: Social and Educational Studies, 4(2), 875-882.

Tójar, C. (2006). Investigación cualitativa. Comprender y actuar. Madrid: La Muralla.

Tour, E. (2017). Teachers' self-initiated professional learning through personal learning networks. Technology, Pedagogy and Education, 26(2), 179-192. 
Appendix: Scale of competence assessment

\begin{tabular}{|c|c|c|}
\hline \multicolumn{3}{|c|}{ STUDENT DETAILS } \\
\hline$A$ & Degree & \\
\hline$B$ & Course & \\
\hline $\mathrm{C}$ & Subject & \\
\hline $\mathrm{D}$ & Age & \\
\hline \multirow[t]{9}{*}{$E$} & Gender & \\
\hline & Previous studies & \\
\hline & City & \\
\hline & Father's age & \\
\hline & Mother's age & \\
\hline & $\begin{array}{l}\text { Father's academic } \\
\text { degree }\end{array}$ & $\begin{array}{l}\text { Elementary studies: } \\
\text { Secondary school/Bachelor: } \\
\text { Professional Training: Module: } \\
\text { Degree: } \\
\text { PhD: }\end{array}$ \\
\hline & $\begin{array}{l}\text { Mother's academic } \\
\text { degree }\end{array}$ & $\begin{array}{l}\text { Elementary studies: } \\
\text { Secondary school/Bachelor: } \\
\text { Professional Training: Module: } \\
\text { Degree: } \\
\text { PhD: }\end{array}$ \\
\hline & Father's job & \\
\hline & Mother's job & \\
\hline
\end{tabular}




\section{INSTRUCTIONS TO FILL OUT THE QUESTIONNAIRE:}

1. Read carefully, one by one, each question.

2. When you have read it, answer by marking with a cross $(X)$, according to the following scale:

1: Strongly disagree 2: Disagree 3: Agree 4: Strongly agree NS/NC: Unknown/ No answer

\begin{tabular}{|c|c|c|c|c|c|c|}
\hline & ITEM & 1 & 2 & 3 & 4 & NS/NC \\
\hline A) & ORGANIZE AND PROMOTE SITUATIONS & & & & & \\
\hline A.1. & $\begin{array}{l}\text { Knowing the theoretical contents is } \\
\text { necessary to face the explanation in their } \\
\text { teaching work. }\end{array}$ & & & & & \\
\hline A.2. & $\begin{array}{l}\text { Teachers must have developed knowledge } \\
\text { about the different methodological issues } \\
\text { that may be developed in their profession. }\end{array}$ & & & & & \\
\hline A.3. & $\begin{array}{l}\text { It is important to be able to use social and } \\
\text { communicative skills required for the } \\
\text { development of the teacher's professional } \\
\text { activities. }\end{array}$ & & & & & \\
\hline A.4. & $\begin{array}{l}\text { The teacher has to be constantly innovative } \\
\text { in his or her classes. }\end{array}$ & & & & & \\
\hline A.5. & One must avoid daily routines. & & & & & \\
\hline A.6. & $\begin{array}{l}\text { Teachers have to analyze if they awaken } \\
\text { curiosity, motivation, and if they are able to } \\
\text { make their teaching interesting. }\end{array}$ & & & & & \\
\hline A.7. & He has to know how to teach discipline. & & & & & \\
\hline A.8. & $\begin{array}{l}\text { Adapting to learning situations proposed by } \\
\text { the student is key. }\end{array}$ & & & & & \\
\hline A.9. & $\begin{array}{l}\text { Teachers must know different types of } \\
\text { resources to use inside and outside the } \\
\text { classroom. }\end{array}$ & & & & & \\
\hline A.10. & $\begin{array}{l}\text { Entrepreneurship and initiative of students } \\
\text { and colleagues is important. }\end{array}$ & & & & & \\
\hline A.11. & $\begin{array}{l}\text { The ability to orient students towards } \\
\text { learning must be developed. }\end{array}$ & & & & & \\
\hline A.12. & $\begin{array}{l}\text { Teachers must know how to link theoretical } \\
\text { content to the students' reality (they must } \\
\text { know how to find usefulness). }\end{array}$ & & & & & \\
\hline B) & TEAMWORK & & & & & \\
\hline & TEACHER MUST: & & & & & \\
\hline
\end{tabular}




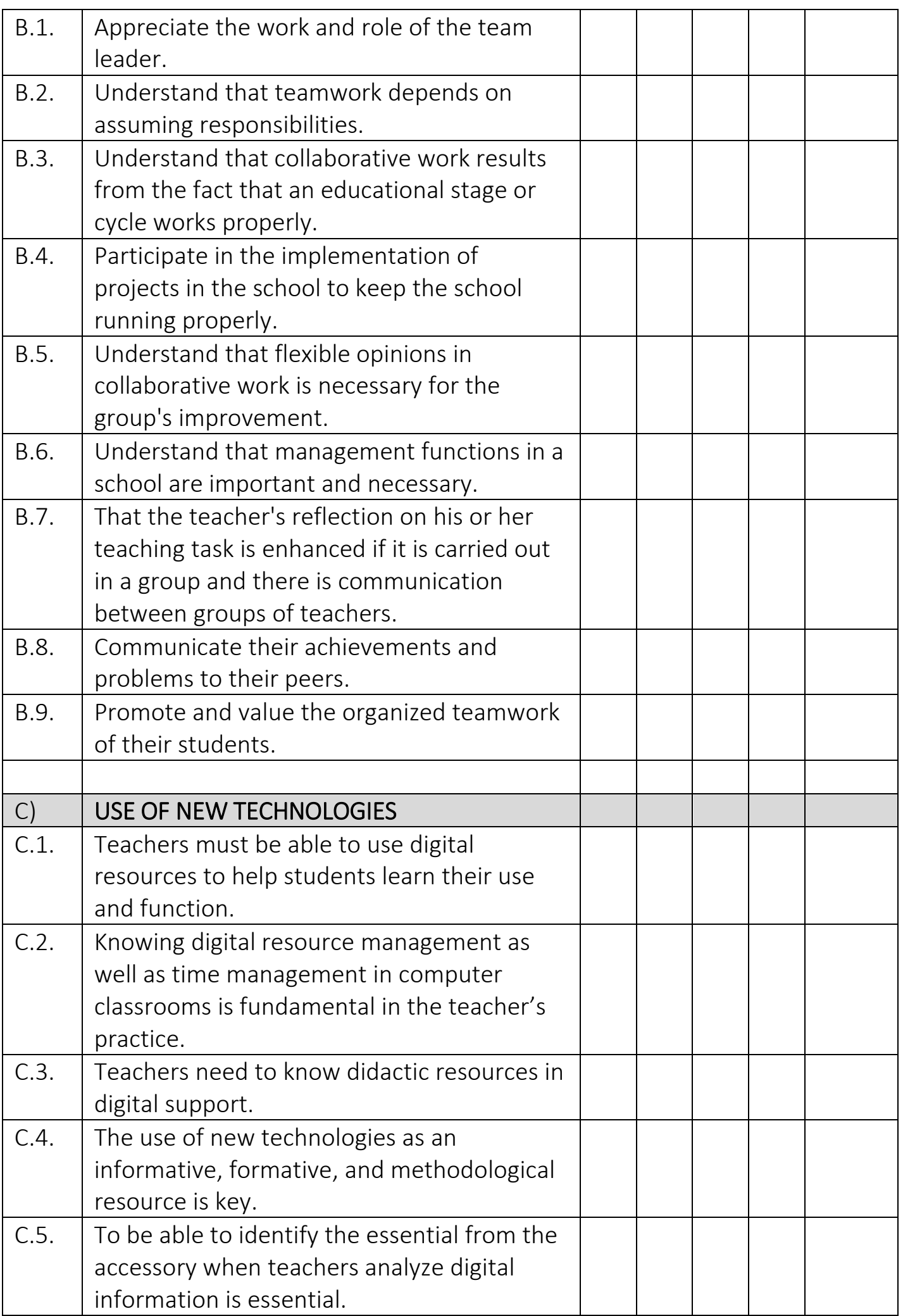




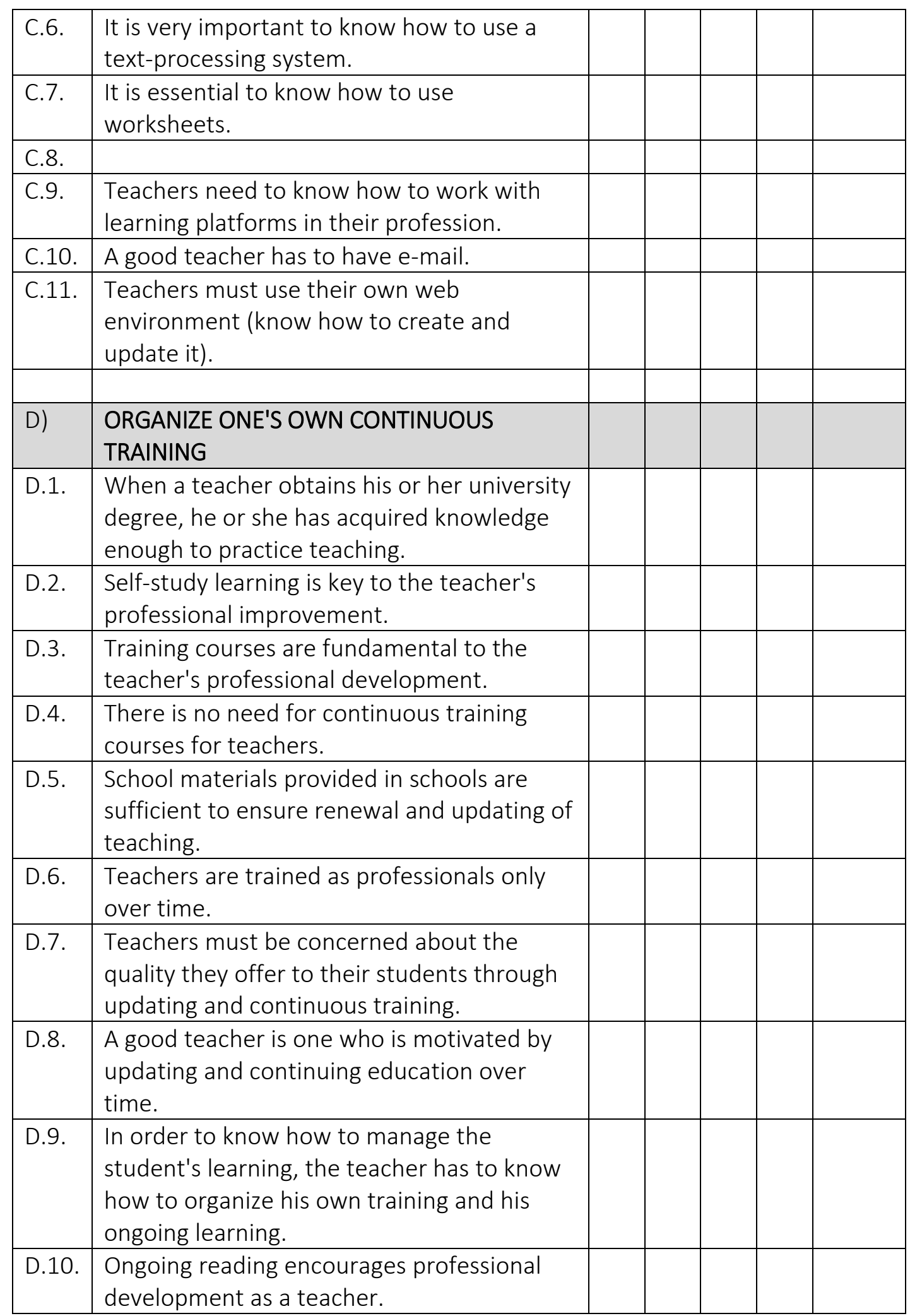




\begin{tabular}{|l|l|l|l|l|l|l|}
\hline D.11. & $\begin{array}{l}\text { Participation in school projects enables } \\
\text { teachers to be permanently and constantly } \\
\text { updated. }\end{array}$ & & & & & \\
\hline & & & & & & \\
\hline
\end{tabular}

